\title{
Spontaneous penoscrotal bleeding in haemophilia $\mathrm{A}$
}

\author{
Shahid Akhtar Siddiqui, Vasudha Tomar
}

Department of Pediatrics, Moti Lal Nehru Medical College, Allahabad, Uttar Pradesh, India

\section{Correspondence to} Dr Shahid Akhtar Siddiqui, sha.akht@yahoo.com

Accepted 25 October 2016

\section{CrossMark}

To cite: Siddiqui $S A$, Tomar V. BMJ Case Rep Published online: [please include Day Month Year] doi:10.1136/bcr-2016217596

\section{DESCRIPTION}

A boy aged 3 years presented to the emergency department with sudden onset of painless penoscrotal swelling and ecchymosis of 2 days. There was no history of trauma or similar presentation before this episode. No family history of bleeding disorder was present. On examination, his vitals were stable. Temperature of the scrotum and penis was normal. There was penoscrotal oedema and ecchymosis with loss of scrotal rugosities and normal shape of penis (figure 1). His blood investigations were unremarkable except for prolonged aPTT. Factor assay was performed which came out to be moderate factor VIII deficiency $(3.4 \mathrm{IU} / \mathrm{dL})$. The patient was started on intravenous recombinant factor VIII as per World Federation of Haemophilia (WFH) protocol. ${ }^{1}$ Bleeding was con-

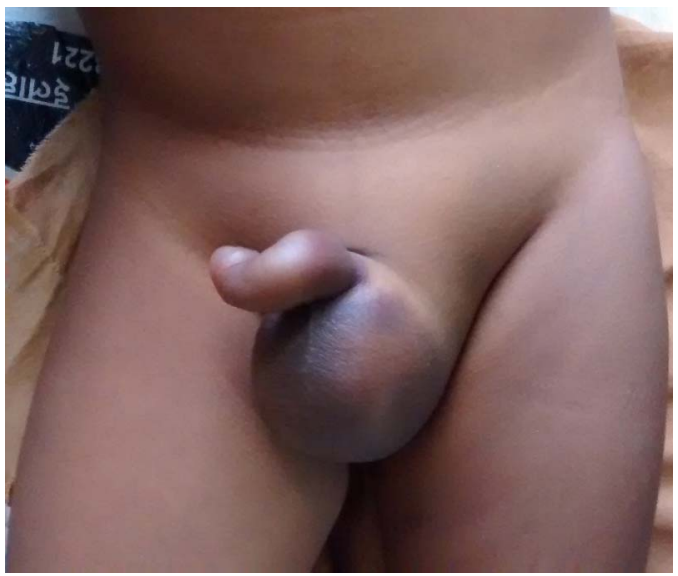

Figure 1 Picture showing penoscrotal oedema and ecchymosis with loss of scrotal rugosities. firmed on high-resolution ultrasonography scan of the scrotum. The patient had an uneventful recovery in a week.

\section{Learning points}

- Deficiencies of factor VIII and IX are the most common severe inherited bleeding disorders. Haemophilia has a high rate of spontaneous mutation and in the absence of positive family history, it may go undiagnosed in infants and toddlers. $^{2}$

- Severe and extensive bleeding may occur in open compartmental haemorrhages like in the retroperitoneal space, scrotum, buttocks or thighs.

- All known and suspected cases of haemophilia should be assessed regularly for tachycardia, hypotension and increasing pallor.

Contributors SAS worked up the case and prepared the final manuscript. VT managed the case, reviewed the literature and wrote the manuscript.

Competing interests None declared.

Patient consent Obtained.

Provenance and peer review Not commissioned; externally peer reviewed.

\section{REFERENCES}

1 Srivastava A, Brewer AK, Mauser-Bunschoten EP, et al., Treatment Guidelines Working Group on Behalf of The World Federation of Hemophilia. Guidelines for the management of Hemophilia. Haemophilia 2013;19:e1-47.

2 Kliegman RM. Nelson textbook of pediatrics. 1st South Asia Edition. New Delhi: Elsevier;2016:2384-8.

\footnotetext{
Copyright 2016 BMJ Publishing Group. All rights reserved. For permission to reuse any of this content visit http://group.bmj.com/group/rights-licensing/permissions.

BMJ Case Report Fellows may re-use this article for personal use and teaching without any further permission.

Become a Fellow of BMJ Case Reports today and you can:

- Submit as many cases as you like

- Enjoy fast sympathetic peer review and rapid publication of accepted articles

- Access all the published articles

- Re-use any of the published material for personal use and teaching without further permission

For information on Institutional Fellowships contact consortiasales@bmjgroup.com

Visit casereports.bmj.com for more articles like this and to become a Fellow
} 